\title{
Assessment of Genotoxic Effect Induced by Some Antidepressant Drugs Employing a Variety of Short-Term Genotoxic Bioassays
}

\author{
Ereeny B. Elias ${ }^{1}$, Mohamed A. Elseehy ${ }^{1}$, Mohamed O. Abd El Fattah, ${ }^{2}$ and Sara A. Aggag ${ }^{1}$
}

\begin{abstract}
This investigation was carried out to evaluate genotoxicity of two important antidepressants medications (namely, Sertraline (four Modabex doses) and Carbamazepine (four Tegretol doses) on albino mice, Mus musculus, via molecular and cytological studies. pharmacogenomic gene (Cytochrome P450 4B1 gene) was employed as marker for detecting critical dose for antidepressant drug and monitoring its affect with different doses extracted from exposures, amplified and sequenced. Cytological studies reflected Robertsonian Centric Fusion (RCF), Ring Chromosome (RC), chromosomal aberrations for tests tissue treated with fourth Sertraline dose. Furthermore, Stickiness (S), chromatide deletion (CD), Ring Chromosome (RC) aberrations for bone marrow tissue treated with second Carbamazepine dose. Nevertheless, chromosomal aberrations for tests tissue treated with fourth Sertraline dose. Highly affect of Sertraline dose for tests tissue on was detected for third dose as a result of lowest similarity percentage $(60 \%)$ which indicated affection of these doses. Interestingly the same antidepressant drug (Sertraline) with the same dose (third Modabex) which cause highly affect on Cytochrome P450 4B1gene in tests tissue, it recorded lowest affect in bone marrow sample. Based on Cytochrome P450 4B1gene sequence, influence of Sertraline on tests sample was dissentingly as 71, 72, 59, 55 and $69 \%$ of genetic similarity percentage. Highly affect of Carbamazepine was detected under first dose. Second Carbamazepine dose has no influence as a result of Cytochrome P450 4B1gene sequence for untreated and treated with second dose for tests sample. For 68,83 and $73 \%$ of genetic similarity percentage were recorded between Cytochrome P450 4B1gene sequences which isolated form bone marrow (with different doses) and Cytochrome P450 4B1reference gene sequence. Genetic evaluation of Sertraline and Carbamazepine cleared that, third Modabex dose and first Tegretol dose could be considered as critical doses.
\end{abstract}

Keywords: Sertraline, Carbamazepine, Cytochrome P450 4B1, Mus musculus

\section{INTRODUCTION}

Depression is a major public health problem, affecting more than $16 \%$ of adults during their lifetime. Thus, Antidepressant medication is widely used as the current standard treatment for depression. Antidepressants may improve depressive symptoms by acting on emotional neural systems .(American Psychiatric Association, 2013, 2006).

Neuropsychological mechanism by which antidepressants act to improve depressive features remains underspecified. For example, it is unclear whether antidepressants alter emotional states by reducing negative emotional neural processes, increasing positive emotional processes or both. Depressed patients exhibit an attention bias away from positive emotions (Ma, 2015).

Sertraline, a selective serotonin reuptake inhibitor (SSRI) class antidepressant, is the most prescribed psychiatric medication in the United States. Sertraline caused hepatic cytotoxicity and mitochondrial impairment. In sertraline-treated cells, the induction of apoptosis and cell death was shown to be the result of activation of $\mathrm{JNK}$, but not ERK1/2 or p38 in the mitogen-activated protein kinase (MAPK) pathway. Generally, sertraline induced apoptosis in HepG2 cells at least partially via activation of the TNF-MAP4K4JNK cascade signaling pathway (Chen et al., 2014).

Carbamazepine is an antiepileptic drug, chemically related to the Tricyclic Antidepressants. It is an iminostilbene-derivative with a carbamyl moiety at the 5 th position of the molecule. Carbamazepine has been successfully employed in a variety of neurological and psychiatric disorders. Furthermore, Carbamazepine monotherapy is one of the most frequently prescribed antiepileptic drug therapies. It has also been tried in alcohol withdrawal seizures. It also has mood-stabilizing (Panday et al., 2017).furthermore, Carbamazepine (CBZ) toxicity and effects was investigated on transaminases like glutamate oxaloacetate transaminase (GOT) and glutamate pyruvate transaminase (GPT); lactate dehydrogenase (LDH) activities in gill, liver and muscle of a freshwater fish, Cyprinuscarpio . During acute treatment, GOT activity was decreased in all the organs (gill, liver and muscle); GPT and LDH activities were increased in liver and muscle while decreased in gill. During sub lethal treatment, GOT activity was decreased in liver and muscle, whereas GPT activity was increased in these two organs. (Malarvizhi et al., 2012).

Cytochrome P450 (CYP) describes a class of hemecontaining proteins that represent the major enzymes

\footnotetext{
${ }^{1}$ Department of Genetics, Faculty of Agriculture (El-Shatby), Alexandria University

${ }^{2}$ Department of Genetic Engineering, El-Sadat University

Received April 23, 2017, Accepted May 11, 2017
} 
responsible for the oxidation and reduction of numerous endogenous substrates and drugs. More than 50 iso enzymes that catalyze the oxidation of diverse drugs and chemicals are known so far. In humans, the most relevant cytochromes are CYP1A, CYP2A6, CYP2B6, CYP2C8, CYP2C9, CYP2C19, CYP2D6, CYP2E1 and CYP3A. More than 400 individual forms of cytochromes have been found in humans, and further studies may identify other relevant ones. Variations in CYP2D6 have been associated with a vast list of diseases (e.g., arterial hypertension, leukemia, childhood apnea, ${ }^{13}$ thyroid cancer, Alzheimer disease and Parkinson disease, hepatic disease, pulmonary disease, breast cancer, porphyrias) and with people's ability to metabolize antidepressants. Personalized medicine is one of the most promising aspects of contemporary medicine, and it may be achieved by the adaptation of therapies to individual patients by means of genetic and other molecular tools. Most pharmacogenetic studies investigate genes related to metabolism, those that code for receptors and transporters and those related to second-messenger systems (Porcelli et al., 2012).

Different cytological studies present a huge tool for antidepressant genotoxicity evaluation. For example, Micronuclei are cytoplasmic chromatin masses with the appearance of small nuclei that arise from chromosome fragments or intact chromosome lagging behind in the anaphase stage of cell division (Celik et al., 2008). Moreover, alkaline comet assay and the cytokinesisblock micronucleus (CBMN) assay were used to investigate genotoxicity potential of sertraline in the peripheral blood lymphocytes (PBLs). For acute sertraline who had caused much more DNA damage in comparison with chronic treatment $(\mathrm{p}<0.05)$.

Relation between antidepressants (AD) and cancer (CA) was studied. Some suggest an association between use of $\mathrm{AD}$ and increased risk of $\mathrm{CA} \cdot{ }^{1-10} \mathrm{CA}$ is a potentially fatal disease. suggesting a positive weak association between use of antidepressants and tumoral growth. increased risk of cancer associated with antidepressants are still conflicting. In most studies the multivariate analysis did not show positive association between use of antidepressants and cancer, unless in specific cases, such as Hodgkin's lymphoma (Bôaventura et al., 2007).

\section{MATERIALS AND METHODS}

To evaluate affect of different antidepressant drugs namely, Sertraline (four Modabex doses) and Carbamazepine (four Tegretol doses); Cytochrome P450 4B1 gene which considered a main pharmacogenomic gene was studied. Extraction, amplification and sequencing protocols were employed for Cytochrome
P450 4B1 gene which isolated from Tests and Bone marrow tissues. For detecting genetic influence of antidepressant drugs (namely, Sertraline and Carbamazepine), comparison among Cytochrome P450 4B1 gene sequence for untreated and under different doses of different antidepressant drugs (namely, Sertraline and Carbamazepine which prepared as follow: Modabex commercial formula for Sertraline, dissolved one tablet in $100 \mathrm{ml}$ double distilled water, $33.3 \mathrm{ml}, 25$ $\mathrm{ml}$ and $20 \mathrm{ml}$ for preparing first, second, third and fourth Sertraline doses, then $200 \mu \mathrm{l}$ were doses orally for five House mouse(Mus musculus) for each dose. Tegretol (syrup, 2\%) commercial formula for Carbamazepine was prepared as $120.5,620.5,875$ and $1250 \mu 1$ and doses orally for albino mice, Mus musculus.

\section{Experimental animal model:}

A total of 32 male albino mice, Mus musculus, (25$30 \mathrm{~g})$ were purchased from the Medical Research Institute Alexandria University. The animals were kept in plastic cages (four animals per cage) covered with metallic grids in a room maintained at proper environmental conditions of temperature $25^{\circ} \mathrm{C}$ and humidity $50 \%$ with a 12 -hours light-dark cycle. The animals were acclimatized for 4 weeks before the start of the experiment and they were given free access food and water. All animals were observed daily for abnormal signs.

\section{Experimental animal groups:}

Thirty two male albino mice were divided randomly into two groups. The duration for all experimental groups was 60 days.

-Group A: Modabex commercial formula for Sertraline was treated for this group, dissolved one tablet of Modabex in $100 \mathrm{ml}$ double distilled water, $33.3 \mathrm{ml}, 25$ $\mathrm{ml}$ and $20 \mathrm{ml}$ for preparing first, second, third and fourth Sertraline doses, then $200 \mu \mathrm{l}$ were doses orally for five Mus musculus albino mice for each dose.

-Group B: Tegretol commercial formula for Carbamazepine was treated for this group which consists on for five Mus musculus albino mice for each dose. Tegretol (syrup, 2\%) commercial formula for Carbamazepine were prepared as 120.5, 620.5, 875 and $1250 \mu \mathrm{l}$ and doses orally.

\section{A- Molecular studies:}

\section{Preparation of samples for molecular studies:}

At the end of the experiments ( 24 hours after the last dose of the Modabexand Tegretolthe mice were killed under proper ether anesthesia following overnight fast. This study was carried out in the Genetic Engineering and Biotechnology Research Institute (University of Sadat City). 
Table 1. Specific Primers sequence under study

\begin{tabular}{|c|c|c|c|}
\hline \multirow{3}{*}{ 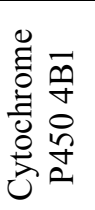 } & \multicolumn{2}{|r|}{ Primer Sequences } & Target \\
\hline & CYP4B1-1 & 5-CACTGGTAATTTTTCAGATGG-3 & $266 \mathrm{bp}$ \\
\hline & CYP4B1-2 & 5-ССТCТАТАAАCACССТTGCA-3 & 2.bp \\
\hline
\end{tabular}

\section{Collection of the samples:}

The present work was performed on tests and Bone marrow tissues which were collected in EDTA coated tubes for complete analysis, centrifuged at $2000 \mathrm{xg}$ for $10 \mathrm{~min}$ to separate plasma and stored at $-80^{\circ} \mathrm{C}$ until analysis. The tests and Bone marrow tissues were immediately removed, washed twice with ice-cold saline solution.

\section{A.1. DNA Extraction}

For DNA extraction, from Tests and Bone marrow tissues. Albino mice, Mus musculus samples were collected in $2 \mathrm{ml}$ of each on EDTA tube as anticoagulant. Genomic DNA was isolated from blood samples using PureLink ${ }^{\circledR}$ Genomic DNA Mini Kit (Thermo Scientific/K182001). DNA concentration was determined using spectrophotometer and the final concentration was adjusted up to $50 \mathrm{ng} / \mu \mathrm{l}$ and stored at $4^{\circ} \mathrm{C}$ for PCR analysis

\section{A.2. PCR reaction}

DNA amplification was performed for amplified Cytochrome P450 4B1 specific gene .Thus, CYP4B1-1 and CYP4B1-2. Table (1) listed specific primer for this study which performed according to manufacturer protocol. Then, PCR product were purified from gel with GeneJET PCR Purification Kit (Thermo Scientific/ K0701)

\section{A.3. Data analysis:}

Gel documentation system (Geldoc-it, UVP, England), was applied for data analysis using Totallab analysis software, ww.totallab.com, (Ver.1.0.1). Aligned sequences were analyzed on NCBI website (http://www.ncbi.nlm.nih.gov/webcite) using BLAST to confirm their identity. The Genetic distances and Multi Alignments comparision were computed by Pairwise Distance method using ClusteralW software analysis (www.ClusteralW.com). The nucleotide sequences were also compared with Cytochrome P450 4B1 reference sequences available in the GenBank.

\section{B. Cytological study:}

\section{B. 1. Analysis of chromosomal abnormalities in mice bone-marrow cells:}

Three hours prior to killing, the animals were injected with $0.6 \mathrm{mg} / \mathrm{kg}$ of colchicinesafter killing, the adhering soft tissue and epiphyses of both tibiae were removed. The marrow was aspirated from the bone, transferred to phosphate buffered saline, centrifuged at $1000 \mathrm{rpm}$ for 5 minutes and the pellet re-suspended in $0.075 \mathrm{M} \mathrm{KCl}$. Centrifugation was repeated and the pellet was re-suspended in fixative (methanol: acetic acid, $3: 1$ ). The fixative was changed after 2 hours and the cell suspension was left overnight at $4^{0} \mathrm{C}$.

\section{B. 2. Slide preparation and staining:}

Cells in fixative were dropped onto very clean glass slides and air-dried. Spreads were stained with $10 \%$ Giemsa at PH 6.8 for $5 \mathrm{~min}$.

\section{B. 3. Screening of slides:}

Slides were coded and scored for chromosomal aberrations e.g., gaps and deletion, fragment, break, stickiness and polyploidy. A mitotic index based on at least 200 cells was recorded. For chromosomal abnormalities at least 200 scorable metaphase cells per dose were recorded.

\section{RERSULTS AND DISCUSSION}

This investigation was carried to evaluate influence of different antidepressant drugs (namely, Sertraline and Carbamazepine on mice genome. For achieving this aim, main pharmacogenomic gene (Cytochrome P450 4B1 gene) was employed as marker for detecting critical dose for antidepressant drug and monitoring its affect with different doses. Thus, Cytochrome P450 4B1 gene was extracted from exposures tests and bone marrow, amplified and sequenced. Cytochrome P450 4B1 gene Sequences for treated and untreated tests and bone marrow samples were alignment and compared with reference sequence on database. Thus, genetic variations were accurately detected for antidepressant drugs under study and critical antidepressant drugs doses was evaluated. Photograph (1 and 2) showed specific Cytochrome P450 4B1 gene product on agarose gel with remarkable $660 \mathrm{bp}$ and $246 \mathrm{bp}$ respectively. Two specific fragments were detected for all treated and untreated samples with different intensity values. Cytochrome P450 4B1gene sequences for treated and untreated tests and bone marrow samples and genetic similarity among treated and untreated tests and bone marrow Cytochrome P450 4B1gene sequences (Table. 2 ), indicated that highly affect of Sertraline dose for tests tissue on Cytochrome P450 4B1gene was detected 
for $\mathrm{M} 3$ as a result of lowest similarity percentage $(60 \%)$ which indicated affection of this doses which resulted as distinguishable variation on Cytochrome P450 4B1gene sequence. Interestingly the same antidepressant drug (Sertraline) with the same dose M3 which cause highly affect on Cytochrome P450 4B1gene in tests tissue, it recorded lowest affect in bone marrow sample. Superior genetic similarity percentage $(94 \%)$ between Cytochrome P450 4B1gene sequence (which extracted from bone marrow) and reference gene. Based on Cytochrome P450 4B1gene sequence, influence of Sertraline on tests sample was dissentingly as $71,72,59$, 55 and $69 \%$ of genetic similarity percentage. Founded data indicate that, first Sertraline dose cause the lowest affect comparing with third dose. On the other hand, influence of Sertraline on bone marrow sample was dissentingly as $60,94,65,74,65 \%$ of genetic similarity percentage. The obtained data indicated that, first Sertraline dose reflect the lowest affect comparing with second and fourth doses. Carbamazepine influence was detected on Cytochrome P450 4B1gene sequence which extracted and amplified from tests tissue. It was found that, influence of Sertraline on tests sample was dissentingly as 71,68 and $71 \%$ of genetic similarity percentage. Highly affect of Carbamazepine was detected under first dose. Second Carbamazepine dose has no influence as a result of Cytochrome P450 4B1gene sequence for untreated and treated with second dose for tests sample. For 68,83 and $73 \%$ of genetic similarity percentage were recorded between Cytochrome P450 4B1gene sequences which isolated form bone marrow (with different doses) and Cytochrome P450 4B1reference gene sequence. Interestingly, untreated bone marrow sample showed remarkable dissimilarity for Cytochrome P450 4B1 gene which turned to become a highly similarity for after first dose treatment (83\%) and $73 \%$ after second dose treatment. This could be explained in the light of inverted Cytochrome P450 4B1 to its wild sequence after exposure to critical doses of Carbamazepine on distinguishable bone marrow sample. Our obtaining results for applying Cytochrome marker gene was in agreements with findings of Preissner et al., (2013). They indicated that, Differences in drug response can be attributed to variability in DNA sequences of specific genes which's products are crucial for drug metabolism. For instance, SNPs in phase 1 enzymes, such as cytochrome P450 oxidases (CYPs). Clear variation of cytochrome P450 oxidases (CYPs) which we obtained was understood in the light of findings of composition of CYPs in humans varies considerably among individuals because of sex and age differences, the influence of diet, liver disease, presence of potential inducers and/or inhibitors. Because of such factors and CYP polymorphisms, and overlapping drug specificity, there is a large variability in the content and composition of P450 enzymes among individuals (Cederbaum, 2015). Distinguish differentiation of cytochrome-P450 (CYP) which cleared by our results were in agreements with findings of $\mathrm{Mh}$ et al., 2010. This cleared that genetic polymorphisms in CYP2C19 may be influencing S-CIT serum concentrations, and that specific CYP2D6 polymorphisms may be predicting patient treatment outcomes based on gene dosage analyses.

Cytological studies was employed to detect and evaluate genoticity effect of different antidepressant drugs (namely, Sertraline and Carbamazepine) on mice's (Photograpg:3, 4 and 5). Cytological effect for Carbamazepine and Sertraline which cleared in Photograph (1,2, and3) could be concluded as follow, Robertsonian Centric Fusion (RCF), Ring Chromosome (RC), chromosomal aberrations for tests tissue treated with fourth Sertraline dose. Furthermore, Stickiness (S), chromatide deletion (CD), Ring Chromosome (RC) aberrations for bone marrow tissue treated with second Carbamazepine dose. Nevertheless, chromosomal aberrations for tests tissue treated with fourth Sertraline dose. More light was added to our findings by Yilmaz et al.,(2015). They determined In vitro genotoxic effects of trazodone and milnacipran (active antidepressant drugs) in human peripheral blood lymphocytes by using chromosomal aberrations (CAs), sister chromatid exchanges (SCEs), micronuclei (MN), and comet assays. Both of the active ingredients raised the MN frequency in a dose-dependent manner. Mitotic index was significantly decreased, but replication and nuclear division indices were not affected at all treatments. Trazodone was statistically increased the mean comet tail intensity, tail length, and tail moment at three concentrations $(6.25 ; 12.50 ;$ and $25.00 \mu \mathrm{g} / \mathrm{mL})$ compared with control. Two highest concentrations (50 and $75 \mu \mathrm{g} / \mathrm{mL}$ ) of trazodone were toxic in the comet assay. Milnacipran increased the comet tail intensity, tail length, and tail moment at all concentrations. It is concluded that trazodone and milnacipran have clastogenic, mutagenic, and cytotoxic effects on human lymphocytes in vitro. Our obtaining results was in agreements of Saxena R1, Ahuja YR. (1988). They evaluatedwo tricyclic antidepressants, amitriptyline and imipramine for their in vitro cytogenetic effects. frequencies of chromosome aberrations and SCEs were significantly increased at concentrations 4 and 40 times the plasma level $(1,000$ and $10,000 \mathrm{ng} / \mathrm{ml})$ although the actual increases was small. The mitotic index was not affected at any concentration. 


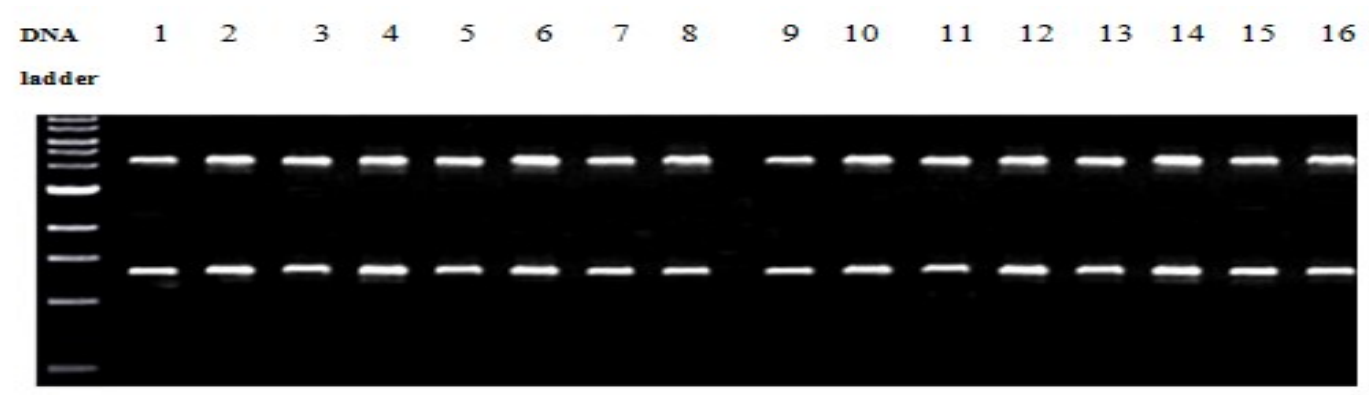

\begin{tabular}{ll}
\hline $\begin{array}{l}\text { Figure 1. Cytochrome P450 4B1 gene sequence for tests } \\
\text { tissue. }\end{array}$ & $\begin{array}{l}\text { Figure 2. Cytochrome P450 4B1 gene sequence for } \\
\text { tests tissue treated with first Sertraline. }\end{array}$ \\
\hline $\begin{array}{l}\text { Figure 3. Cytochrome P450 4B1 gene sequence for tests } \\
\text { tissue treated with second Sertraline. }\end{array}$ & $\begin{array}{l}\text { Figure 4. Cytochrome P450 4B1 gene sequence for } \\
\text { tests tissue treated with third Sertraline. }\end{array}$ \\
\hline $\begin{array}{l}\text { Figure 5. Cytochrome P450 4B1 gene sequence for tests } \\
\text { tissue treated with fourth Sertraline. }\end{array}$ & $\begin{array}{l}\text { Figure 6. Cytochrome P450 4B1 gene sequence for } \\
\text { tests tissue. }\end{array}$ \\
\hline $\begin{array}{l}\text { Figure 7. Cytochrome P450 4B1 gene sequence for tests } \\
\text { tissue treated with first Carbamazepine. }\end{array}$ & $\begin{array}{l}\text { Figure 8. Cytochrome P450 4B1 gene sequence for } \\
\text { tests tissue treated with second Carbamazepine. }\end{array}$ \\
\hline $\begin{array}{l}\text { Figure 9. Cytochrome P450 4B1 gene sequence for Bone } \\
\text { marrow tissue. }\end{array}$ & $\begin{array}{l}\text { Figure 10. Cytochrome P450 4B1 gene sequence for } \\
\text { Bone marrow tissue treated with first Sertraline. }\end{array}$ \\
\hline $\begin{array}{l}\text { Figure 11. Cytochrome P450 4B1 gene sequence for } \\
\text { Bone marrow tissue treated with second Sertraline. }\end{array}$ & $\begin{array}{l}\text { Figure 12. Cytochrome P450 4B1 gene sequence for } \\
\text { Bone marrow tissue treated with third Sertraline. }\end{array}$ \\
\hline $\begin{array}{l}\text { Figure 13. Cytochrome P450 4B1 gene sequence for } \\
\text { Bone marrow tissue treated with fourth Sertraline. }\end{array}$ & $\begin{array}{l}\text { Figure 14. Cytochrome P450 4B1 gene sequence for } \\
\text { Bone marrow tissue. }\end{array}$ \\
\hline $\begin{array}{l}\text { Figure 15. Cytochrome P450 4B1 gene sequence for } \\
\text { Bone marrow tissue treated with first Carbamazepine. }\end{array}$ & $\begin{array}{l}\text { Figure 16. Cytochrome P450 4B1 gene sequence for } \\
\text { Bone marrow tissue treated with second } \\
\text { Carbamazepine. }\end{array}$ \\
\hline
\end{tabular}

Photograph 1. shows specific Cytochrome P450 4B1 gene with remarkable 660 bp and 246 bp respectively

Table 1. illustrated genetic similarity among treated and untreated tests and bone marrow Cytochrome P450 4B1gene equences

\begin{tabular}{|c|c|c|c|c|c|c|c|c|c|c|c|c|c|c|c|c|c|}
\hline 1: EMBOSS_15_ & 100.00 & 89.82 & 82.70 & 59.57 & 54.20 & 65.10 & 62,68 & 63.32 & 61.51 & 50.56 & 62.58 & 66.33 & 50.35 & 52.71 & 65.61 & 66.72 & 67.86 \\
\hline 2: EMBOSS_10_ & 89.82 & 100.00 & 94.16 & 63.02 & 57.37 & 71.14 & 61.25 & 65.69 & 67.02 & 56.15 & 66.52 & 72.75 & 56.03 & 59.80 & 68.84 & 71.38 & 69.48 \\
\hline 3: EMMOSS_1 & 82.70 & 94.16 & 100.00 & 68.44 & 65.28 & 74.27 & 65.26 & 67.88 & 69.37 & & 70.62 & 73.21 & 55.32 & 60.40 & 71.26 & 71.26 & 71.60 \\
\hline & 59.57 & 63.02 & 68.44 & 100.00 & 90.14 & 89.04 & 57.17 & 64.13 & 56.33 & 68.01 & 3.50 & 64.78 & 48.84 & 4.56 & 68.11 & 98 & 99.53 \\
\hline 5: EMBOS & 54.20 & 57.37 & 65.28 & 90.14 & 0.00 & 79.52 & 50.08 & .55 & 52.29 & 51.92 & .38 & 56.45 & 43.89 & .64 & 0.19 & .69 & \\
\hline 6: EMBOSS & 65.10 & 71.14 & 74.27 & 9.04 & 79.52 & 100.00 & 59.09 & 63.32 & 69.66 & & 68.42 & 69.08 & 62.77 & 6.19 & 75.32 & 09 & 7.02 \\
\hline 7: EMBOS & 62.68 & 61.25 & 65.26 & 57.17 & 50.08 & 59.09 & 100.00 & 70.22 & 57.66 & 68.24 & 79.69 & 68.27 & 67.31 & 70.27 & 79.28 & 7.22 & 1.21 \\
\hline 8: El & 63.32 & 65.69 & 7.88 & 4.13 & 59.55 & 3.32 & 70.22 & 100.00 & 3.25 & .76 & .03 & 73.60 & 56.54 & 4.15 & 0.30 & 1.76 & 8.07 \\
\hline & 61.51 & .02 & 69.37 & 6.33 & .29 & 9.66 & 7.66 & 73.25 & 100.00 & .96 & .27 & 84.80 & 69.59 & 3.15 & 7.08 & .06 & 7.93 \\
\hline : EM & 50.56 & 56.15 & 3.80 & 68.01 & 61.92 & 63.59 & 68.24 & .76 & 62.96 & 100.00 & 74.05 & 68.89 & 67.78 & 0.97 & 73.74 & .03 & 6 \\
\hline$E M$ & 62.58 & 66.52 & 70.62 & 68.50 & 63.38 & 68.42 & 79,69 & 77.03 & 80.27 & 74.05 & 100.00 & 86.77 & 67.45 & 72.58 & 89.19 & 94,49 & 91.17 \\
\hline & 66.33 & 72.75 & 73.21 & 64.78 & 56.45 & 69.08 & 68.27 & 73.60 & 4.80 & 68.89 & 86.77 & 100.00 & 62.17 & 66.24 & 80.91 & 84.27 & 1.37 \\
\hline & 50.35 & 56.03 & 55.32 & 8.84 & 43.89 & 62.77 & 67.31 & 56.54 & 9.59 & 67.78 & 45 & 62.17 & 100.00 & 85 & 74.43 & 75,40 & 73.9 \\
\hline$E$ & 52.71 & 59.80 & 60.40 & 64.56 & 57,64 & 76.19 & 70.27 & 64.15 & 68.15 & 70.97 & 72.58 & 66.24 & 90.85 & 100.00 & 79.59 & 80.16 & 79.17 \\
\hline & 65.61 & 68.84 & 71.26 & 68.11 & 60.19 & 75.32 & 79.28 & 80.30 & 87.08 & 73.74 & 89.19 & 80.91 & 74,43 & 79.59 & 100.00 & 93.41 & 92.6 \\
\hline & 66.72 & 71.38 & 1.26 & 69.88 & 60.69 & 76.09 & 77.22 & 81.76 & 91.06 & 78.03 & 94.49 & 84.27 & 75.40 & 80.16 & 93.41 & 100.00 & 97.3 \\
\hline : EMBC & 67.86 & 69.48 & 71.60 & 69.53 & 60.49 & 77.02 & 75.21 & 78.07 & 87.93 & 75.03 & 91.17 & 81,37 & 73.95 & 79.17 & 92.62 & 97.39 & 100. \\
\hline
\end{tabular}




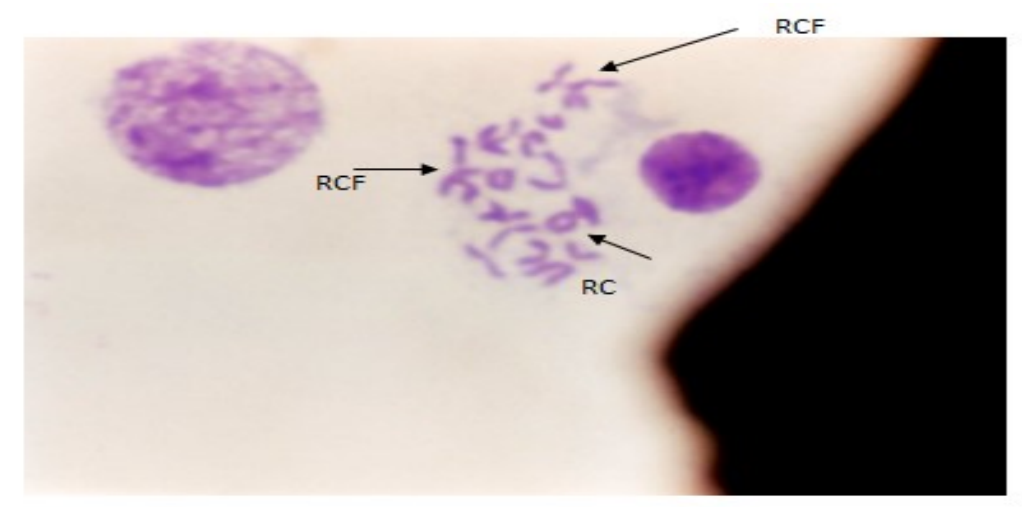

Photograph 3. Robertsonian Centric Fusion (RCF), Ring Chromosome (RC), chromoromal aberrations for tests tisuue treated with fourth Sertraline dose

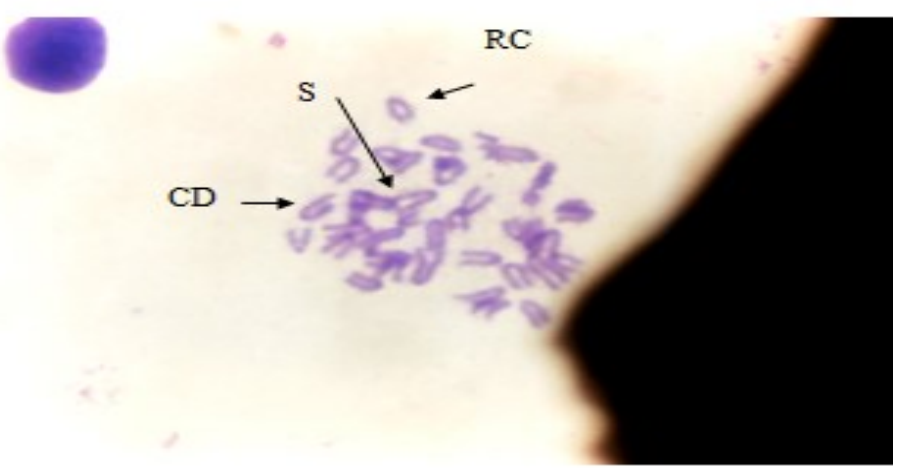

Photograph 4. Stickiness (S), chromatide deletion (CD), Ring chromosome (RC) aberrations for bone marrow tissue treated with second carbamzepine dose

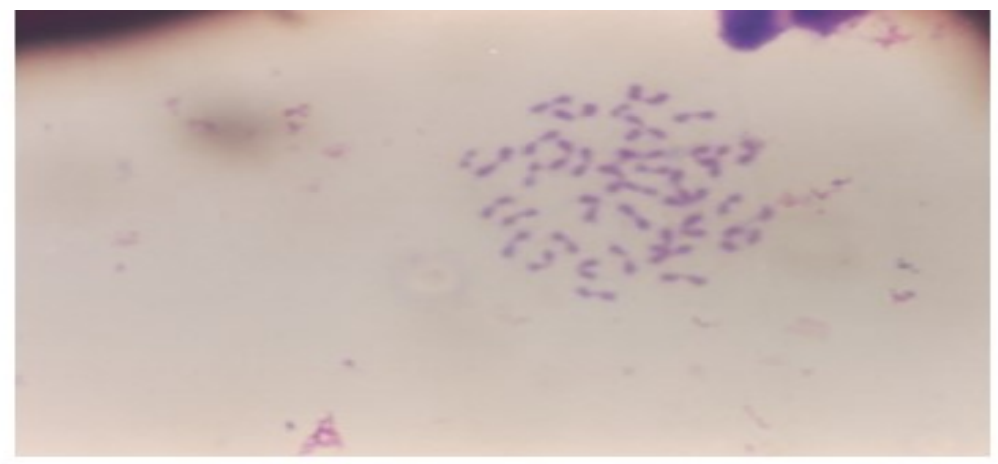

Photograph 5. Eroded surface chromosomal aberrations for tests tissue treated with fourth Sertra1ine dose

Through imipramine showed a significant increase in chromosome damage at the upper plasma level and at concentrations higher than that, SCE frequency was significantly increased only at concentration higher than the plasma level $(5,000 \mathrm{ng} / \mathrm{ml})$, the actual increase being small for both these parameters. Our cytological data were supported by Madrigal-Bujaidaret al., (2010). They determined Imipramine (IMI) and desipramine
(DES) (two drugs widely used for the treatment of depression) capacity to induce chromosomal aberrations in mouse bone marrow cells. significant increase in chromosome damage with the doses tested for each compound: 7, 20, and $60 \mathrm{mg} / \mathrm{kg}$ in the case of IMI, and 2,20 , and $60 \mathrm{mg} / \mathrm{kg}$ as regards DES. This last drug induced stronger chromosomal damage than IMI. Moreover, micronuclei Induction and sister chromatid 
exchanges were appeared and suggest caution with respect to their use in long-term treatments.

Distinguishable affection of Sertraline and Carbamazepine was clear in the light of presented data of Xia (1999)and Slamon et al.,(2001). They indicated that antidepressants genotoxic may be related with their potential to increase the number of reactive oxygen species.

\section{REFERENCES}

American Psychiatric Association. 2006. Practice guideline for the treatment of patients with major depressive disorder.. Practice Guidelines for the Treatment of Psychiatric Disorders: Compendium, 2nd edn, American Psychiatric Association.2013. Arlington VA, USA, pp 763-840.

Annamalai Malarvizhi, Chokkalingam Kavitha, Manoharan Saravanan, Mathan Ramesh. 2011.Carbamazepine (CBZ) induced enzymatic stress in gill, liver and muscle of a common carp, Cyprinuscarpio. Journal of King Saud University - Science Volume 24: 179-186.

Bôaventura Camila Silva Andréia Nunes Guimarães; Guilherme Rebello Soares; Anna Milena Barreto Ferreira Fraga; FláviaBrancoCerqueira Serra Neves; Milena Pereira Pondé. 2007. Risk of cancer associated with the use of antidepressants. Revista de Psiquiatria do Rio Grande do Sul. Rev. psiquiatr. Rio Gd. Sul vol.29 no.1.

Cederbaum AI. 2015. Molecular mechanisms of the microsomal mixed function oxidases and biological and pathological implications.Redox Biol. 4:60-73 .

Celik A, Cömelekoglu U, Yalin S. A. 2008. study on the investigation of cadmium chloride genotoxicity in rat bone marrow using micronucleus test and chromosome aberration analysis. ToxicolInd Health 21:243-8.

Chen Si, JiekunXuanLiqing WanHaixia LinLetha CouchNan MeiVasily N. DobrovolskyLeiGuo. 2014. Sertraline, an Antidepressant, Induces Apoptosis in Hepatic Cells Through the Mitogen-Activated Protein Kinase Pathway. Toxico 1Sci 137 (2): 404-415.

Der WeideJ, nd John WJ Hinrichs 2006. The Influence of Cytochrome P450 Pharmacogenetics on Disposition of Common Antidepressant and Antipsychotic Medications.ClinBiochem Rev Feb; 27(1): 17-25.

DilekBattal,, AycaAktas, Mehmet Ali Sungur, ElaKadioglu, EbruDericiEker, NefiseOzlenSahin, SahanSaygi. 2013. In Vivo Genotoxicity Assessment of Sertraline by Using Alkaline Comet Assay and the Cytokinesis-Block Micronucleus Assay. Basic \&Clinical Pharmacology \&ToxicologyVolume 113: 339-346.

Ece AvulogluYilmaz, FatmaUnal \& DenizYuzbasioglu. 2017. Evaluation of cytogenetic and DNA damage induced by the antidepressant drug-active ingredients, trazodone and milnacipran, in vitro.Journal Drug and Chemical Toxicology, Volume 40: Issue 1.

Fava M. 2013. Diagnosis and definition of treatment-resistant depression. Biol Psychiatry . 53: 649-659.
Ma Y. 2015. Neuropsychological mechanism underlying antidepressant effect: a systematic meta-analysis. Mol Psychiatry. 2015 Mar;20(3):311-9.

Madrigal-Bujaidar E. Cárdenas García Y. I. ÁlvarezGonzález. 2010. Chromosomal aberrations induced by imipramine and desipramine in mouse. Human and Experimental Toxicology. 29(4): 297-302.

Malarvizhi A., Kavitha C., Saravanan M., Ramesh M. 2012. Carbamazepine (CBZ) induced enzymatic stress in gill, liver and muscle of a common carp, Cyprinus carpio. Journal of King Saud University - Science. 24: 179-186.

MH Tsai, Lin KM, Hsiao MC, Shen WW, Lu ML, Tang HS, Fang CK, Wu CS, Lu SC, Liu SC, Chen CY, Liu YL. 2010. Genetic polymorphisms of cytochrome P450 enzymes influence metabolism of the antidepressant escitalopram and treatment response. Pharmacogenomics. 11(4):537-46.

Pandey D., Pandey R. and Garg P. K. 2017. Neoadjuvant Therapy and Lymphadenectomy in Esophageal Cancer: Both Are Essential to Maximize Survival Benefit. Ann Surg. 2017 Apr; 265(4):e41-e42.

Porcelli S, Fabbri C and Serretti A. 2012. Meta-analysis of serotonin transporter gene promoter polymorphism (5HTTLPR) association with antidepressant efficacy. Eur Neuropsychopharmacol. 2012 Apr;22(4):239-58.

Preissner SC, Hoffmann MF, Preissner R, Dunkel M, Gewiess A and Preissner S. 2013. Polymorphic Cytochrome P450 Enzymes (CYPs) and Their Role in Personalized Therapy. PLoS ONE 8(12): e82562. https://doi.org/10.1371/journal.pone.0082562.

Saxena R, Ahuja Y. R. 1988. Genotoxicity evaluation of the tricyclic antidepressants amitriptyline and imipramine using human lymphocyte cultures.Environ Mol Mutagen. 12(4):421-30.

Slamon LD, Ward TH, Butler J, Pentreath VW. 2001. Assessment of DNA damage in C6 glioma cells after antidepressant treatment using an alkaline comet assay. Arch Toxicol. 75: 243-250.

Stefano Porcelli, MD, Antonio Drago, MD, Chiara Fabbri, Sara Gibiino, MD, RaffaellaCalati, PsyD, PhD, andAlessandroSerretti, MD, PhD. 2011. Pharmacogenetics of antidepressant response.J Psychiatry Neurosci. 36(2): 87-113.

Trivedi MH, Rush AJ, Wisniewski SR, Nierenberg AA, Warden D, Ritz L et al. 2006. Evaluation of outcomes with citalopram for depression using measurement-based care in $\mathrm{STAR}^{*} \mathrm{D}$ : implications for clinical practice. $\mathrm{Am} J$ Psychiatry . 163: 28-40.

Xia Z, 1999. Changes in the generation of reactive oxygen species and in mitochondrial membrane potential during apoptosis induced by the antidepressants imipramine, clomipramine, and citalopram and the effects on these changes by Bcl-2 and Bcl-X (L).BiochemPharmacol .57: 1199-1208.

Yilmaz. 2015. Neuropsychological mechanism underlying antidepressant effect: a systematic meta-analysis. Molecular Psychiatry . 20: 311-319. 


\section{الملخص العربي}

تقييم الأثر السام وراثيا المستحدث بواسطة بعض مضادات الاكتئاب بتوظيف مجموعة من اختبارات

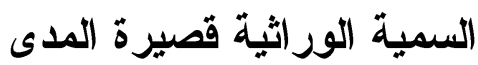

ايريني برسوم، محمد عبد الباعث الصيحي، محمد عثمان عبد الفتاح، سارة امجد عجاج التان

aberrations

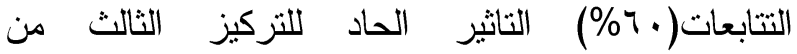
السيرتير الين عن معاملته لانسجه الخصيه التاثير الواضح

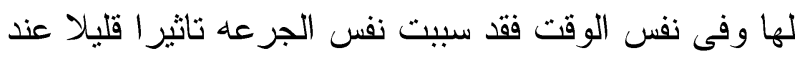
خراسه التاثير على خلايا نخاع العظام. ولقد بلغت نسبه Cytochrome P450 4B1 التشابه الور اثى فى تتابعات الجين على انسجه الخصيه المعاملة بالسيرتير الين , 69, 55, 59, 72

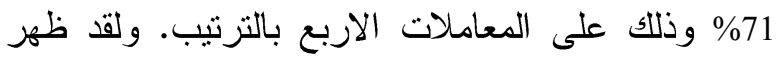
الاثر الوراثى الحاد للكربامازبين فى جرعنه الاولى بينما انعدم التاثير للجرعه الثانيه وذللك بالنسبه لانسجه الخصيه. ولقد بلغت نسبه النتابه الوراثى فى تتابعات الجين Cytochrome P450 4B1 للكربامازبين 73, 83, 68 وذللك على المعاملات الاربع بالتزتيب وذللك بالنسبه لخلايا نخاع العظام. وفى النهايه فيمكن استخلاص كفاءه الدلائل الور اثيه و السيتولوجيه فى لئ

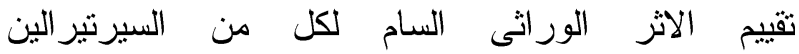
و الكربامازبين التى اتضح منها انه يمكن اعتبار كل من التركيز الثالث والاول لكل من السيرتير الين والكربامازبين

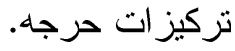

تهدف هذه الدراسة الى نقييم الاثر الور اثى السام لاثثين

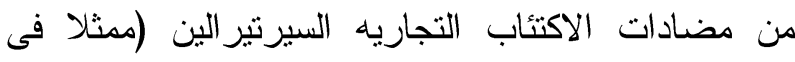
اربع جرعات من المنتج المودابكس) و الكربامازبين (ممثلا فى اربع جرعات من المنتج التجريتول) التى تم تطبيقها عل فئزان التجارب البيضاء Mus musculus وذلك من خلال الدراسات الجزيئيه و السيتولوجيه. ولقد نم استخدام الجين ذو

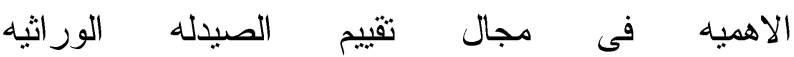
(CytochromeP450 4B1 gene) الخصيه ونخاع العظام المعامل بكلا مضادى الاكتئاب،

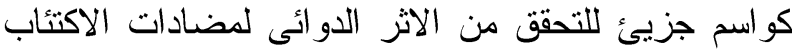
تحت الدراسة وذلك عن طريق تتبع التخيرات الحادثه فى تتابعات القواعد النيتروجينيه للجين تحت الدراسة. ولقد اوضحت الدراسات السيتولوجية وجود عدد من الثذذوذات reflected Robertsonian Centric الكروموسوميه مثل ونل Fusion (RCF), Ring Chromosome (RC), chromosomal aberrations فى خلايا انسجه الخصيه المعامله بالثركيز الر ابع من السيرتير الين. بالاضافه لذلك فقد عكست خلايا

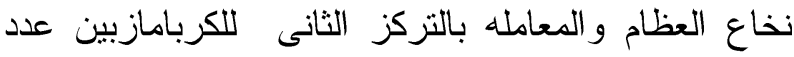

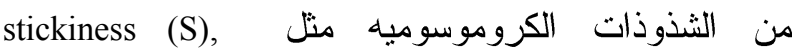
chromatide deletion (CD) Ring Chromosome (RC) 